\title{
Sistem Açısından Din Eğitimine Bir Bakış
}

\author{
Dr. Fatih Menderes BILGILI* \\ Güzel Yalı Mah., 22. Sok., Atakan Apt. 4/2, Çukurova-Adana \\ Ömer YAVUZ \\ Yurt Mah., 71451 Sok., Gören Apt. 12/23, Çukurova-Adana
}

\section{Özet}

Din eğitimi çalışmaları, eğitilecek varlıktan bağımsız yapılamaz. Bu sebeple eğitimi hazırlayanlar ve verenler eğitilecek varlığın ait olduğu sistemleri çok iyi tanımalıdır. Aksi takdirde verilen eğitimle istenilen sonuca ulaşılamaz. Hatta zararları bile olabilir. Öte yandan insan, öğrenen bir sistemdir. Buradaki öğrenme teknikleri ve yöntemleri çağın bilimsel (ilmî) yapısı çerçevesinde olmalıdır. Bu bağlamda din eğitiminde verilen doğa ve Kur'an ayetlerini anlamak için kullanılacak yöntem çok önemlidir. Yanlış yöntemler bizleri yanlış uygulamalara götürür. Din eğitiminde verilen konuları anlamada kullandığımız yöntem de bir sistem olmalıdır. Yani doğa ve Kur'an gibi insan ürünü olmayan (kompleks) sistemleri anlamada kullanılacak yapının da bir sistem olması gerekir.

Anahtar Kelimeler: Din eğitimi; Sistem; İlmî dil; Sistem dışı; İlmî metodoloji. 


\title{
An Overview of Religious Education System
}

\begin{abstract}
Studies on religious education can not be done independently without the human beings to be educated. For that reason, the people who prepare and apply the education should know the systems which the human beings take part in. Otherwise the desired and can not be reached by the applied education. Moreover, it can even cause damages. On the other hand, human being is a learning system. The learning techniques and methods must be in the frame of contemperary scientific structure. In this context, the methods which will be used to understand the nature and Qur'an verses, are very important. Wrong methods will take us to wrong results. The method which we use to understand the given subjects in religious education should be a system. It means that the structure to be used in understanding the complex systems such as nature and Qur'an which are not human-made products is required to be a system.
\end{abstract}

Keywords: Religious education; System; Scientific language; Non-system; Scientific methodology.

\section{Extended Summary}

\section{Purpose}

The human being is composed of biological, psychological and sociological components. In order to utilize these componets properly, one should accurately read the systems formed by Nature and the Koranic surahs and establish relationships with each other, understand their purposes well. It is very important to try to listen and understand what they have to say from a scientific point of view.

Nature and the Koranic surahs support each other in conveying the Creator's messages. This support is important in terms of the message being understood. If we accept the written text as an intel- 
lectual abstraction, Nature itself is an intellectual concretization. The fact that the transition from the intellectual absctraction to the intellectual concretization occurs word by word is indicative of the quality of the message being understood.

Therefore, we can describe the human being as a "Biosocial, complex-adaptive, purpose oriented learner, information-processing, cybernetic, dynamic system” (Özenli, 1999, s.3).

It is not an educator's duty to pass down only the formal information stated in the curriculum. Besides, his/her duties include to maintain a positive bahaviour model in the mind of the learning system (the one being educated). It is also their duty to enable the students to gain skills in solving the problems which they will face and the basic principles of scientific and technological thinking and investigation.

\section{Results}

The concept of system plays a vital role in understanding Creation, education and forming the scientific method. Therefore, a consensus must be achieved on the subject of the concept of system and the meanings associated with the concept. In analysing any entity or phenomenon and using them in education, we need to determine the system they belong to and their limitations. Otherwise, we cannot come to sound decisions about the entities in question. Consequently, this causes some confusion.

The system that is meant here is the set of components joined together in regular interaction to form a coherent whole.The ele- 
ments belonging to the system are parts of the system and each part joining together is in interaction with each other. In every age, equilibrium and relations stating this interaction and bond are analysed in detail in the humanities as well as in the sciences. The entities in hand must fulfil at least the following two conditions:

1. They should form an interacting whole

2. They should have a continuous and regular interaction with each other

\section{Methods}

It is important to do epistemic studies for phases of a qualified understanding. These studies use our physical system as material. The product we get is used in desiging formal education. Religious education should certainly utilize these studies. One should refer to the universe and the guidance of the systems forming it while planning religious education curriculum and application techniques.

In determining and obtaining methods, the systems which the material used belong to is utilized. Methods can not and must not be prepared independently of materials and vice versa. When examinining the Koranic surahs in this connection, we see that they have excluded nothing concerning and affecting human beings.

\section{Discussion}

When planning and applying religious education, we should take the followings into consideration:

1. Determination of which scientific system the subject to be taught 
belongs to.

2. Determination of which methods to be used in examining the subject and the system which the subject belongs to.

3. Determination of the system which the educator belongs to.

4. Determination of the system which the one to be educated belongs to.

All components making up the human beings should be analysed systematically because the human being is the object of the religious education. These analyses enable the religious education obtained through scientific gains to crystallize in the course of time.

We should reach a concensus between the human language and the language of the Koranic surahs versus.

Firstly, strong bridges should be constructed between these two languages. If the bridge is not constructed strongly, it is impossible to be establish suitable and desired crossings from one side to the other. Also, system infringements can be occured.

\section{Conclusion}

Each scientific discipline has their own area of knowledge. Each of these areas is called as a system. Each sysytem represents a system. These constitute sub-systems of the general system.

Each scientific discipline tries to form a part of the whole. Therefore, excluding something from these disciplines means rubbing out a part of the picture. Saying something about only part of a whole is like saying nothing about the whole. This prevents us from seeing the whole 
of the picture and it also hinders necessary education.

When analysing an entity belonging to our world in religious education, all components concerning it little or much should be scientifically determined. Otherwise, we can not obtain good quality and reliable information about the entity in question.

On the other hand, a curriculum based on the Koranic surahs about Nature can not be static. Because the systems belonging to these surahs are dynamic.

\section{Giriş}

İçinde yaşadığımız evren hakkında bilgi eksikliğimiz azaldıkça, onu daha iyi tanımaya ve anlamaya başlarız. Anlama sürecimize, birçok ilmî disiplin eşlik eder. Yani, evrenimizi anlamak için, birçok ilmî disiplin ortak çalışmalar yürütür. Evren hakkında astronomlar, matematikçiler, fizikçiler, biyologlar, kimyacılar ve bilim felsefecileri, sanki görev bölümü yapmış gibi, çalışmalarını sürdürmektedir. Bunlardan her biri kendi sahasında kazı çalışmalarını yaparlar. Yapılan bu zihnî kazılar sayesinde, hem varlığı hem de varlık düzlemindeki yerimizi, daha iyi anlarız. Bu bağlamda evrenimiz, anlamamızı sağlayan, bir araç hüviyetindedir.

Birçok ilmî disiplin, evreni anlama sürecimiz esnasında doğmuştur. İslâm düşüncesinde, bu ilmî disiplinlerin her biri, anlam ve temel esaslar açısından, bir bütünün parçası olarak kabul edilir. $\mathrm{Bu}$ anlamda, aslında her bir disiplin, kendi penceresinden, evrenimizin 
resmini çizmektedir. Bu nedenle, üstünlük açısından, bilimlerin birini diğerine tercih etmek, yanlış olur (İbn Cemaa, 1998, s. 64).

Disiplinlerin birbirine karışıp, karmaşanın çıkmaması ve her birinin kendi sınırları içerisinde ilerleyip, üst yapılı semantik ilişkiyi (korelasyon), sağlıklı bir şekilde kurması için; bu disiplinler, farklı başlıklar altında ele alınmıştır. Dolayısıyla, bu disiplinleri, dinî veya dinî olmayan şeklinde bir ayrıma tâbi tutmak da, doğru değildir. Zira, gerek Allah'ın sözlerini içeren Kur'an kitabında ve gerekse Allah'ın yarattığı kâinat kitabında, böyle bir ayrımın olmadığını, rahatlıkla görürüz. Kısaca ifade etmek gerekirse, varlıkları meydana getiren bileşenlerden sadece biri hakkında bir şeyler söyleyip diğerleri hakkında bir şeyler söylememek aslında varlıklar hakkında hiçbir şey söylememektir.

Aynı şeyleri, Kur'an hakkında da söyleyebiliriz. Kur-an'1 Kerim, birçok ilmî disiplini içinde barındırır. Bu disiplinlerden sadece bir veya bir kaçını göz önüne alıp diğerlerini göz ardı etmek, doğru değildir (Nasr, 2006, s.4). Zira Kur-an'1 Kerim de, kendi içerisinde bir sistemdir. Ayetlerin meydana getirdiği bu sistem, ilmî sistemdir. İlgili ayetler bir araya gelerek, bu sistemin alt sistemlerini meydana getirir. Bu sistemler, ancak belli usuller (metot) çerçevesinde incelendiğinde, kendini gösterir.

Kur'an sistemine, mânâ ve mazmun açısından baktığımızda, matematik-mantık yapısına sahip olduğunu görürüz. Beyanların çelişkisiz ve bir bütün olması, bizi bu sonuca götürmektedir. Aynı şekilde, 
doğada da tamlık (komple) ve tutarlılık (konsistan) görülür. Bu zaviyeden bakıldığında, Kur'an'ın anlatmak istediği mesajlar kümesi ile doğanın anlatmak istediği mesajlar kümesinin, eşdeğer olduğunu söylemek mümkündür (Bilgili ve Yavuz, 2011). Ancak, vahyin ele aldığ1 bilgi kümesinin, sistem dışına ait bilgiler de vermesiyle, tabiatın ele aldığı bilgi kümesinden, farklılık gösterdiği unutulmamalıdır. Doğa ve Kur'an, sistem açısından incelenirse, bu sonuca varmak mümkündür.

Buna göre, doğa ve Kur'an ayetleri, bir bütün oluşturmaktadır. Bunların her biri, insanlara ilahî mesajları ulaştırır. Dolayısıyla, bunları inceleyen ilim dallarına karşı, gereken önem verilmelidir. Aksi takdirde, Allah'ın ayetleri arasında ayrım yapılmış, veya, gereken önem verilmemiş olur. Ayetler arasında yalıtım uygulamak da, istenilen sonuca ulaştırmaz, hatta yanlışlıklara sebep olur.

$\mathrm{Bu}$ konuda, çoklu-disiplin (multi-disipliner) yaklaşımının çok önemli olduğunu düşünüyoruz. Bu yaklaşım sayesinde, ilmî metodoloji daha kapsamlı bir hâle gelir. İlmî metodoloji ilmî disiplinleri, ilmî disiplinler de ilmî metodolojiyi besler. Bu sebeple, doğa ve Kur'an ayetlerini gereği gibi anlamak için, ilmî yöntemlerin vazgeçilmez olduğunu söyleyebiliriz. Ayrıca bu yaklaşım tarzı, ilmî disiplinler arasındaki ilişkiyi de zorunlu kılar.

Her bir ilmî disiplin, bütünün bir parçasını oluşturmaya çalışır. $\mathrm{Bu}$ sebeple, bunlardan herhangi birini dışarıda bırakmak, resmin bir bölümünü silmek anlamına gelir. Daha önce de ifade etmeye çalıştığımız gibi, sadece bütünün parçası hakkında bir şeyler söylemek, bütün 
üstüne hiçbir şey söylememektir. $\mathrm{Bu}$ da, hem resmin tamamını görmemizi, hem de kendimizi gereği gibi inşa etmemizi engeller. Dolay1sıyla, insana kazandıracağı yetenekler açısından da, ilmî disiplinlerin hepsi çok önemlidir.

Kur'an ayetlerini bu bağlamda incelediğimizde, insanı ilgilendiren ve etkileyen, hiçbir şeyi dışarıda bırakmadığını görürüz. Bu ilmî anlayışın prensiplerini ortaya koyan İslâmiyet, evrenimizi Allah'ın bir eseri olarak görürken; Kur’an-1 da onun kâinat hakkındaki sözlerinin bir özeti olarak değerlendirmektedir. Buna göre; evren de o sözlerin bir açılımıdır. Bu açıdan baktığımızda, Kur'an-1 Kerim'i, kâinatın kelimelere dökülmüş hâli olarak görebiliriz.

İlim dilinin sağladığı imkânlarla, din eğitiminin temelini teşkil eden Kur'an'ı anlamaya çalışmanın, birbirine eşdeğer ve nitelikli sonuçlar çıkarmamıza yardımcı olacağını söyleyebiliriz. Ancak bu çaba itibar kazandıracak düşüncesiyle değil de özellikle kişinin eğitiminde önemli rol oynadığından dolayı olmalıdır. Yani işlenecek konuların daha iyi idrak edilmesi ve bunun eğitiminin daha iyi verilmesi için bilim dilinin imkânlarını kullanmak gerekir. Yoksa bu dilin ortaya çıkmasına katkı sağlayan bazı kimselerin ideolojilerine Kur'an'ı benzetme gibi bir yaklaşım tarzımız yoktur.

Din eğitiminde ilmî çalışmaların önemli bir rolü vardır. Gerek konuların anlaşılmasında ve gerekse bunun eğitiminin nasıl verileceği konusunda bilimden ve ilmî metodolojiden yararlanmamız bir zorunluluktur (Bilgin, 1995, s. 50). Kullanılan kelimelerin kendi literatürü- 
müze yabancı olması onun tahakkümü altında olmayı gerektirmez. Zira hâkim ilmî gücün temsilcilerine benzemekle, onların doğadan elde ettiği ilmî bağlamdaki kazanımlarını kullanmak birbirinden farklı şeylerdir.

Bilim dilinin hâlihazırdaki İslâm literatürüne yabancı olması veya bu literatürde bu dilin olmaması kültürümüzün acziyetinden kaynaklanmaz. Ancak kendi tembelliğimizin bir göstergesi olabilir. Bilim dilinin mutlaka insana kazandıracağı yaklaşım tarzları vardır. Bunların anlamı ve kazandırdıklanı üzerine yoğunlaşmak daha doğru olur. Aksi takdirde farkında olmadan ilmî kazanımlara düşmanlık yapılır. Bunu yaparken de din adına yaparız da farkında bile olmayız. Ne yazık ki bazı konularda bunun örneklerine rastlamaktayız. Fakat bunlara burada yer veremiyoruz. Bunlar başka çalışmaların konusu olabilir.

Öte yandan bazı bilim adamlarının tavırlarını ve kendi toplumlarında yaşadıkları tecrübeleriyle ortaya çıkan din anlayışını evrenselleştirip İslâmiyet'i de aynı şekilde değerlendirmek büyük bir haksızl1ktır. Kur'an'ın ortaya koyduğu İslâm dinini, diğer dinlerle aynı kategoride görmek insanı geri dönüşü zor olan yollara girdirir. Üstelik Kur'an'ın; insanı ilgilendiren her konuya işaret ettiği ortadadır (Kur'an, 30:58). Bunu belli sahaya hapsetmek büyük bir yanılgıdır. Böyle yapanlar Kur'an'a inandıklarını söyleseler de bu durum onu anlamadıklarının bir göstergesidir. Bu bağlamda Kur'an ayrı bir sistem olarak karşımıza çıkmaktadır. Bu nedenle önce; sistem konusundan kısaca bahsetmemiz gerekir. 


\section{Sistem Nedir?}

İlmî ve teknolojik çalışmalarda sistem kavramı ile sürekli karş1laşılmaktadır. Herhangi bir yapı sistem olabilmesi için gerekli ve yeterli ölçütlere sahip olmalıdır. Bu ölçütler kâinat ayetlerinin çizdiği çerçevede akılsal fonksiyonları kullanarak elde edilir. Bu sebeple ölçütler mutlak değildir. İlmî veriler ile değişip gelişebilir.

Herhangi bir olayı, varlığı veya ayeti incelemeden önce onun hangi sisteme ait olduğunu araştırırız. Gözlemlerimiz göstermiştir ki insan yapımı olmayan varlıklar kesinlikle bir sisteme aittir. Bu varlıklar ait oldukları sistem veya sistemlerle organik bir ilişki içindedirler. Somut veya soyut bağlamda insanın ortaya koyduğu ürünleri incelemeden önce bunların herhangi bir sistemin parçası olup olmadığına veya bunların bir sistem oluşturup oluşturmadığına bakarız. İncelememizi daha sonra devam ettiririz.

İnsan ürünü olan eğitim programları için de aynı şeyleri söyleyebiliriz. Din eğitimi de bunlardan bağımsız değildir. Eğitimin içeriğini ve uygulama yöntemlerini hazırlarken yararlandığımız materyaller bir sisteme ait olmalı veya bir sistem oluşturmalıdır. Aynı şekilde bunlardan yola çıkarak elde ettiğimiz yapının da bir sisteme ait olması veya bir sistem oluşturması gerekir. İncelenen sistemin tamlığı (komple) ve tutarlılı̆̆ (konsistan) için bu şarttır.

Varlıkları anlamada, bunların eğitiminin verilmesinde ve ilmî metodolojinin oluşturulmasında sistem kavramı hayatî rol üstlenir. Bu sebeple sistem kavramı ve bu kavrama yüklenen anlamlar konusunda 
uzlaşma (konsensüs) sağlanmalıdır. Herhangi bir varlığı veya olayı incelerken ve bunları eğitimde kullanırken öncelikle bunların ait olduğu sistemi ve sınırlarını tespit etmemiz gerekir. Aksi takdirde göz önüne alınan varlıklarla ilgili sağlıklı kararlara varamayız. Neticede bu durum zihnî kargaşaya neden olur. Kısaca ifade etmek gerekirse, sistem tanımı üzerinde uzlaşmaya varmamız bir zorunluluktur.

Öncelikle biz burada sistem kavramından ne anladığımızı ifade edelim. "Sistem, organize bir bütün meydana getirmek üzere birbirine düzenli bir etkileşim ile bağlı bileşenler topluluğudur. Ayrıca sistem, belirli bir gayeyi gerçekleştirmek için gerekli olan; düzenli ve kesintisiz biçimde birbirini izleyen (ardıl veya ardışık), operasyonlar ve prosedürler koleksiyonu olarak da tariflenmiştir.” (Özenli, 1999, s.1).

Sisteme ait objeler bu sistemin birer parçasıdır ve her bir bileşen birbirleriyle etkileşim içindedirler. Her çağda bu etkileşimi ve bağlılıkları ifade eden denklemler ve ilişkiler fen bilimlerinde olduğu gibi diğer ilmî disiplinlerde de ayrıntılı olarak incelenmektedir. Göz önüne aldığımız varlıkların sistem meydana getirmesi için kısaca şu iki şartı sağlaması gerekmektedir:

1. Birbirleriyle ilişkili bir bütün oluşturmaları

2. Aralarında sürekli ve düzenli bir etkileşimin olması

$\mathrm{Bu}$ şartları sağlayan yapılara sistem adını verebiliriz. Sistem olma özelliğini haiz yapıları da kendi aralarında mukayese etmek mümkündür. Bu karşılaştırmada birbirinden farklı durumlar ortaya çıkabilir. Farklı sistemlerin mukayesesinde de şu durumlar karşımıza çıkmakta- 
dir:

1. Eşdeğerlilik (izomorfizm)

2. Benzerlik (homomorfizm)

3. Eşdeğer ve benzer olmama (Özenli, 1999, s.3).

Karşılaştırma yapılacak sistemlerin öncelikle elemanları tespit edilmelidir. Daha sonra bunların karakteristik özellikleri ilmî bağlamda ortaya konulmalıdır. Bunlar yapıldıktan sonra sistemler arası karşılaştırmalar yapılabilir. İncelenen sistemlerin karşılaştırılacak elemanları arasındaki özellikler ve bağıntılar birbirlerinin aynısı ise böyle sistemlere eşdeğer (izomorf) sistemler adı verilir. Bu sistemler aynı yapıya sahip olup sadece elemanları farklıdır.

İlmî disiplinlerin her birinin kendisine ait bir alanı vardır. $\mathrm{Bu}$ alanların her birine sistem adı verilir. Her bir sistem bir ilmî disipline karşılık gelir. Bunlar genel sistemin alt sistemlerini oluşturur. Bu sistemler tek başına bir anlama sahiptir. Ancak genel sistem içindeki yeri göz ardı edilmemelidir.

İlmî sistemleri epistemolojik çalışmalar sayesinde elde ederiz. Elde edilen bu sistemlerin hem düşünsel fazda hem de doğada bir karş1lığı vardır. Burada epistemoloji, bilgi teorisi olup bilginin kaynağ1, muhtevası ve sınırlılıkları (limitasyonları) ile anlamanın metot ve süreçlerini (prosedürlerini); natürel bilimlerin kanunlarını; matematik mantık ve sibernetik metotlarını analiz aracı olarak kullanıp inceleyen bir disiplindir (Özenli, 1994, s.54).

Nitelikli anlama fazları için epistemik çalışmalar önemlidir. $\mathrm{Bu}$ 
çalışmalar materyal olarak fizikî sistemimizi kullanır. Elde edilen ürünler formel eğitim inşasında kullanılır. Din eğitimi de bu çalışmalardan istifade etmelidir. Din eğitimi müfredatı ve uygulama teknikleri hazırlanırken evrene ve onu oluşturan sistemlerin rehberliğine başvurulmalıdır.

Evrenimiz alt sistemlerden meydana gelmiştir. Evrenimizi fizikî ve biyolojik olmak üzere iki genel sistem şeklinde tasnif edebiliriz. Aslında biyolojik evrenimiz fizikî evrenimizin bir alt kümesidir. Oldukça belirgin karakteristik özelliklere sahip olduğu için farklı bir başlıkta incelenmektedir.

$\mathrm{Bu}$ çalışmamızda fizikî ve biyolojik evrenimizin ikisine birden yer yer fizikî sistem veya fizikî kâinat tabirlerini kullanacağız. Fizikî evreni oluşturan alt sistemleri de evrenimizin bileşenleri olarak ifade edeceğiz. Bu bileşenler bazen bir varlık bazen de bir olay olarak karŞımıza çıkmaktadır.

Biyolojik yönümüzü buna örnek verebiliriz. Biyolojik yapımız fizikî sistemimize ait bir bileşendir. Bu bileşen alt sistemlerden meydana gelen bir sistemdir. Yani biyolojik sistemimiz sindirim sistemi, boşaltım sistemi, sinir sistemi gibi alt sistemlerden meydana gelmiştir. $\mathrm{Bu}$ sebeple biyolojimizi araştırıp anlamak için birçok ilmî disiplinin ortak çalışması gerekir.

Bizimle ilgili ilk olarak biyoloji disiplini çalışmalarını başlatır. $\mathrm{Bu}$ disiplin kendisine çizmiş olduğumuz sınırlar çerçevesinde sonuçlara ulaşır. Daha sonra kimya disiplini devreye girer. O da kendisine ait 
bölgede incelemelerini yapar. Bir sonraki aşama ve saha fizik disiplinini ilgilendirir. $\mathrm{Bu}$ disiplin de kendisine ayrılan alanda çalışmalarını sürdürür.

Biyolojik yapımızı daha iyi anlamak için bu disiplinlerin ortak çalışmaları gerekir. Bu konuda tam ve tutarlı bir çerçeve çizebilmek için birbirinin içine geçmiş bu disiplinlerin çağın seviyesinde işin içine girmesi elzemdir. Burada her disiplin, bir sistemi incelemektedir. Bu sistemler işleyişte iç içe geçtiğinden bunlar arasında semantik koordinasyonun kurulması da kaçınılmaz hale gelir.

Kısaca din eğitimi verilirken evrenimize ait bir varlık incelendiğinde onunla az veya çok ilgili olan bütün bileşenler tespit edilmelidir. Daha sonra bu bileşenlerin incelediğimiz varlıkla olan irtibatı ve ilişkisi ilmî olarak ortaya konulmalıdır. Aksi takdirde göz önüne aldığımız varlıkla ilgili kaliteli ve sağlıklı bilgiye ulaşamayız.

Din eğitiminde verilecek konuların anlaşılmasında ve bunların aktarılmasında fizikî evrenin ve bileşenlerinin rolü büyüktür. Bunlar tespit edilen referans sisteminde her epistemik seviyede kendisine kulak verenlere mesajlar sunar. Ancak bunların vermek istediği mesajları lâyıkıyla anlamak için; öncelikle bu varlıkların içerisinde bulunduğu organizasyona ait referans sistemlerinin ve sınırlarının açıkça belirlenmesi gerekir. Herhangi bir ilmî araştırmada ele alınan konunun tespit edilen her bir limitasyonuna en genel anlamda sistem adını verebiliriz. Bununla beraber belirlenmiş olan her bir sistem alt sistemlerden meydana gelmiş olabilir. Bu sistemler de ancak doğal varlıklar 
ilmî olarak incelendiğinde açı̆̆a çıkar.

Bu süreçten sonra seçilen referans sisteminin ulaşabileceği s1nırlar belirlenmelidir. Aynı şekilde ayetlerin ait olduğu sistemler için de bu sınırlar tespit edilmelidir. Bu sınırların ötesine geçme söz konusu ise bunu sağlıklı bir şekilde gerçekleştirecek bir üst dilin oluşturulması gerekir. Bu dil de ancak doğal ayetlerden yola çıkılarak oluşturulur.

$\mathrm{Bu}$ üst dilin elde edilmesinde modellemelerin ve tasvirlemenin rolü büyüktür. Tabiat yasalarından yola çıkarak doğa ayetlerini ve mesajlarını anlayabilmek için bunların oluşturduğu sistemlerin sınırları ve bileşenleri, ilmî bağlamda açıkça modellenmeli ve tasvirlenmelidir. Aynı şekilde Kur'an ayetlerini gereği gibi anlamak için de bu ayetleri oluşturan objelerin hangi sisteme ait olduğu öncelikle tespit edilmelidir.

Örneğin içkinin haramlığını ve içilmemesini ifade eden ayet insanın yaşadığ bu sistemin dışında başka bir sisteme ait ayetlerdir. Yine insanın fizik yap1s1 evren sistemine ait iken ruhu ise tamamı ile bu sisteme ait değildir. Bu çerçevede örnekleri çoğaltmak mümkündür. Ancak gerek doğaya gerekse Kur'an'a ait herhangi bir ayetin gelişigüzel sistem tespitinin yapılamayacağı da unutulmamalıdır.

Din eğitimi hazırlanırken ve uygulanırken sistem bağlamında şunlara dikkat edilmesi gerekir:

1. Eğitimi verilecek konunun hangi ilmî sisteme ait olduğunun tespiti 
2. Sistem tespiti yapılan konunun hangi metodolojilerle inceleneceğinin tespiti

3. Eğitimi verenin ait olduğu sistemin tespiti

4. Eğitim verilenin hangi sisteme veya sistemlere ait olduğunun tespiti

Din eğitiminin nesnesi insan olduğu için insanı meydana getiren bütün bileşenlerin sistematik bir analizden geçmesi gerekir. Bu analizler, ilmî kazanımlar neticesinde elde edilen din eğitiminin süreç içinde kristalize olmasını da sağlar.

\section{Din Eğitiminde Kullanılan Materyallere Sistem Açısından Bir Bakış}

İnsan potansiyel (vehbî) yeteneklerle donatılmıştır. İnsanın kendisini geliştirmesinde bu yetenekler önemli rol oynar. Ancak gelişim için bu yetenekler tek başına yeterli değildir. Bunları harekete geçirecek ve işlevsellik kazandıracak bir çevreye ihtiyaç vardır. Fizikî kâinatımız ve içinde bulunduğumuz sosyal yapı bu çevreyi oluşturur.

Fizikî kâinatımız ve onu meydana getiren bileşenler insanın hem biyolojik hem de zihnî bağlamda değişimini ve gelişimini sağlayacak şekilde yaratılmıştır. Zihnî bağlamdaki gelişim insanda tutum ve davranış değişikliklerine yol açar. Bu değişiklikleri yapan fiziki varlıkları incelediğimizde bunların organize bir sistemin bileşenleri olduğunu görürüz.

Fizikî varlıklar bulundukları sistem göz önüne alınıp incelendiğinde insandaki potansiyel yetenekleri gereği gibi harekete geçirir. 
Aksi takdirde bunlar anlamsız veya sadece kısır bir anlam taşıyan y1ğınlar olur. Hatta bu kadar fizikî bir ortama ve varlığa gerek olmadığı sonucuna ulaşılır. Bundan dolayı fizikî varlıkları ve fizikî materyalleri bulundukları sistem içinde anlamaya çalışmak, onlardan bu çerçevede istifade etmek gerekir. Fizikî evrenimizi anlamada matematik bizlere önemli katk1lar sağlar.

Fizikî evrenimizin sergilediği davranışlarda göze çarpan dikkat çekici özelliklerden bir tanesi, onun matematiğin içine nasıl olup da böyle olağanüstü yüksek derecede bir doğrulukla gömülmüş gözüktüğüdür. Fiziksel dünyayı daha iyi anlayıp doğa yasalarına ilişkin incelemelerimizi derinleştirdikçe, görünen o ki fiziksel dünya âdeta buharlaşıp uçmakta ve matematikle baş başa kalmaktayız. Fizik yasalarını daha köklü bir biçimde kavradıkça, matematiğin ve matematiksel kavramların söz konusu dünyasına gitgide daha çok çekilmekteyiz (Penrose, 2005, s.17). Fiziksel dünyamızı meydana getiren bileşenleri matematiğin yardımı ile anlarız. Matematik bu anlamda onların doğru bir şekilde okunmasını sağlayan bir dildir. Bu dil sayesinde fizikî varlıkları tanırız.

Kur'an zihnî bağlamda kendisinden istifade edilecek bu varlıklara ayet ismini vermiştir (Çantay, 1984, s.68). Bu ayetler; gerek kendileri gerek bulundukları sistem içindeki rolleri gerekse tâbi oldukları kurallar ve kanunlar açısından incelendiğinde bunların insanın eğitiminde oldukça önemli işleve sahip olduklarını görürüz. Burada dikkat çekmek istediğimiz husus bu varlıkların, ayetlerin tâbi oldukları sistemleri göz önüne alarak eğitimde kullanılmasıdır. 
Doğal ayetlerin içinde bulundukları sistemi göz önüne almadan yapılan eğitim kişide ayakları yere basmayan, uygulamada kendisinin problemlerini çözmeyen hatta başına iş açan sonuçlar doğurur. $\mathrm{Bu}$ nedenle doğal varlıkların hem kendisi hem de içinde bulundukları sistem kişinin eğitiminde önemli rol oynar.

Evren sistemimizle birlikte ahiret sisteminin de din eğitiminde önemli bir rolü vardır. İnsanın kendisine ve çevresine faydalı olma, zarar vermesini önleme ve benzeri tutum ve davranışları kazandırmada bu husus kullanılabilir. Bunun için ahiret hayatının olduğu ve orada kişinin hesaba çekileceği konusunun kişinin eğitiminde nasıl kullanılacağı ilmî açıdan tespit edilmelidir.

Kısaca ahiret konusu bu olumlu davranışları kazanmada kullanılabilir. Burada ahiret insanı eğitmede kullanılacak bir eğitim materyalidir. Onun varlığını gündeme taşıyarak kişi eğitilebilir. Ancak ahiret ve ona ait bileşenler fizikî sistemimizin bir elemanı değildir. Burada şu soru akla gelebilir. Evren sistemimizin bir elemanı olmayan bu varlıkları evren sistemimizin bir elemanı olan insanın eğitiminde nasıl kullanacağı?

Detaylarına girmeden kısaca şunu söyleyebiliriz. Fizikî sistemimizin kazandırdığı bakış açısından faydalanarak ikinci bir hayatın olabileceğini dolayısıyla hayatın sadece bu hayattan ibaret olmadığını anlatabiliriz. Tekrardan diriltilme olayını da yine fizikî kâinatımızdan yola çıkarak anlatmaya çalışırız. Bu konuda Kur'an'da oldukça fazla ayet vardır. 
Ahiretin varlığına ikna olmak bir eğitim iken onun varlığından yola çıkarak birtakım tutum ve davranışlar kazanmak da bir eğitimdir. Ahiret enstrümanı kullanılarak yapılacak bir eğitimde bu enstrümanın bulunduğu sistemin tespiti öncelikle önemlidir. Sistem analizi yapılmadan gerek onun varlığı, gerekse onun işlevsellik kazanması oldukça zordur.

Sistem analizi yapmadan bu enstrümanın işlevselliği ancak korku zemininde kullanılabilir. Zira kişi böyle bir durumla karşılaşıp cezaya çarptırılacağından korkarak birtakım davranışlarda bulunur. Böyle bir eğitim sadece korku temellidir. İnsanın kişilik kazanmasından daha çok korkudan dolayı bazı şeyleri yapmasını veya yapmamasını sağlar (Tozlu, 1997, s.150). Bu da yaratılış amacına uygun değildir. Kur'an ayetlerini bu açıdan kategorilere ayırabiliriz:

1. Kazanılacak davranışlar

2. Bu davranışları kazandıran materyaller

Materyalleri asıl kabul edip bunun sağladığı gelişimi göz ardı etmek; biraz önce ifade ettiğimiz korku veya ödül zemininde eğitimin sürdürülmesi anlamına gelir. Sadece bunları göz önüne alarak kazanılan davranışlar yaratılış amacına uymadığından aklını gereği gibi kullananları tatmin etmez. Eğer işin doğrusu kaynağından öğrenilmezse Kur'an gibi doğruları anlatan kitaplara ve bunların temsilcilerine düşmanlık başlar.

Biz burada eğitimde kullanılan materyallerin ait olduğu sistemin tespitinden bahsetmekteyiz. Zira bu materyalin ait olduğu sistem tespit 
edilmediğinde onu eğitim aracı olarak sağlıklı bir şekilde kullanmamız mümkün değildir.

$\mathrm{Bu}$ sebeple öncelikle eğitim materyalinin ait olduğu sistem analizi yapılmalıdır. Daha sonra o sistemin bağlı olduğu kurallar ve kanunlar ortaya konulmalıdır. Bunlarla reaksiyona girebilecek ve böylece insanın yeteneklerini fiiliyata geçirecek bir eğitim düzeneği hazırlanmalıdır. Bunun için de aşağıda kısaca belirttiğimiz din eğitiminde rol alan bileşenleri temel alıp ona göre programların hazırlanmasının daha uygun olacağını düşünmekteyiz.

Nitekim peygamberlerin eğitiminde kullanılan materyaller ve uygulanan yöntemler incelendiğinde onların da bu paralelde olduğu görülür. Sadece zaman içinde tezahürler açısından farklılıklar görülür ancak temel seviyede bunlar aynıdır. Çünkü insanı meydana getiren temel bileşenler aynıdır. Onlarda herhangi bir köklü değişiklik olmamaktadır. Din eğitiminde göz önüne alınması gereken bu temel bileşenler şunlardır:

1. Eğiten

2. Eğitilen

3. Eğitimin konusu ve içeriği

4. Eğitimde kullanılan araç ve gereçler (materyaller)

5. Eğitimde kullanılan yöntemler

$\mathrm{Bu}$ bileşenleri bağlamına göre artırmak da azaltmak da mümkündür. Bunlar eğitilecek kişiye göre şekil alır. Eğitilenden bağımsız olarak eğitimin bileşenleri hazırlanamaz, hazırlanmamalıdır. Öncelikle 
eğitilenin biyolojik, psikolojik ve sosyolojik açıdan durum analizinin yapılması; yani tâbi olduğu sistemin bilinmesi kaçınılmazdır. İçinde bulunduğu sistemi göz ardı ederek hazırlanan programların eğitilene fayda sağlama ihtimali oldukça düşüktür (Najmuddin, 1981, s.8/22). Bu sebeple eğitimi hazırlayan ve verenler eğitilecek varlığın ait olduğu sistemleri çok iyi tespit edip içselleştirmelidir. Aksi takdirde eğitim ile istenilen sonuca ulaşılamaz. Hatta zararları bile olabilir.

$\mathrm{Bu}$ nedenle din eğitimi; olabildiğince eğitilen merkezli olmak durumundadır (Selçuk, 1990, s.65). Burada verilen bilginin yerine ulaştırılmasında ve verim elde edilmesinde eğiten rehberlik yapar. $\mathrm{Bu}$ anlamda eğitim, "eğiticinin, eğitilenin aklını kontrol ettiği tipik bir kontrol prosesidir.” (Özenli, 1999, s.3). Bunun için öncelikle; öğrenen sistemlerin merkezinde bulunan insan iyi tanınmalıdır. Yani insanın ait olduğu sistemlerin ve bu sistemlerde geçerli olan ilmî yapının açıkça ortaya konulması gerekir.

İnsanı meydana getiren bileşenler ve bu bileşenlerin kendisini fonksiyonel kıldığı sistemler faydalı ve ekonomik bir eğitim programı hazırlamada vazgeçilmez bir gerekliliktir. Bu sistemler ilmî analizlemeler neticesinde elde edilmelidir. Analiz yapmak gerçekten de kendimizi sınırlandırmak demektir. Çünkü araştırılan nesneler teoriler ile sınırlıdır ve onlar hakkında söyleyebileceğimiz şeyler de aksiyomlar, tanımlar ve çıkarım kurallarından ibarettir. Ancak, aynı zamanda hakikati arıyorsak onu bulacağımız yol da budur (King, 2003, s.121).

$\mathrm{Bu}$ yöntemin sağladığ katkılar ile insanı meydana getiren bile- 
şenleri tespit edebiliriz. İnsan bu bileşenler sayesinde dinamik bir hüviyete sahiptir. $\mathrm{Bu}$ bağlamda insanı: "Bio-sosyal, kompleks-adaptif, gaye ve yönelik öğrenen, enformasyon prosesleyen, sibernetik, dinamik bir sistem" olarak tanımlayabiliriz (Özenli, 1999, s.3).

İnsanı meydana getiren bileşenleri ve bunların ait olduğu sistemleri tespit etmek eğitim için gereklidir fakat yeterli değildir. İnsanı harekete geçirecek ve ona dinamik bir yapı kazandıracak programın hazırlanması ve uygulanması gerekir. Burada eğitimcinin vazifesi sadece müfredatta belirtilen formel bilgileri aktarmak değildir. Bunun yanında öğrenen sistemin (eğitilen) aklında olumlu ve yapıcı davranış modeli kazandırmaktır. Ayrıca öğrencinin karşılaşacağı problemlerin çözümü için gerekli olan beceri, ilmî ve teknolojik araştırma düşünce ve temel ilkelerini kazandırmaktır. Ancak burada öğrencinin bir bakıma kendi kendisinin öğretmeni olduğu fark ettirilmelidir (Özenli, 1999, s.2).

İnsan özgür iradeli bir varlıktır. Bu sebeple kişi kendisini inşa etme sürecine girmelidir. Bu açıdan bakıldığında insanın öğrenen bir sistem olduğunu söyleyebiliriz. İnsan vehbî (genetik) yeteneklerini, kullanma neticesinde (kesbiyet) geliştirir. Bu süreçte kullanılan teknikler ve yöntemler çağın ilmî yapısı çerçevesinde olmalıdır.

Eğitilen, bu eylemi gerçekleştirirken çevresel şartlara en uygun düşünce ve davranışı sağlayacak şekilde kendisini ayarlamalıdır. Bununla birlikte din eğitiminde verilen bilgilerin işlevsel olanını ve bu bilgilerin geçerlilik sınırlarını bulmaya çalışmalıdır. Bu bir süreçtir. 
Hem eğitimci hem de eğitilen bu sürecin değerlendirmelerini sürekli olarak yapmalidir.

Din eğitimi; tespit edilen sistemler ve bu sistemlerin işleyişleri çerçevesinde performans gösterecek şekilde; programlanmalı ve uygulanmalıdır. Her performans hem eğitimciye hem de eğitilene deneyim kazandırır. Bu iki değişskenin birbirine göre değişimi devamlı olarak denetlenmelidir. Bu ikisinin doğru orantılı olarak arttığı gözleniyorsa ve bu artış ürünün kalitesini sağlıyorsa uygulanan eğitimin niteliğinden bahsedebiliriz. Bu arada performans ve deneyim bir sonraki din eğitimi uygulamalarında billurlaşma (kristalizasyonu) sağlayacaktır.

Performans ve deneyim mekanizması aynı sistem içinde ve aynı materyallere göre istenilen şekilde, nitelikli ve dinamik bir hüviyet gösterir. Eğitilenin ait olduğu sistemlerden sürekli olarak gelen veriler bu mekanizmayı aktifleştirir. Hem eğitimci hem de eğitilen bu mekanizmanın işleyiş̧ini ve verdiği ürünleri en iyi şekilde değerlendirerek düşünce ve eyleminde gerekli değiş̧iklikleri yapmalıdır.

Yeni bilgiler sistem anlayışını ve o sistemde verimli olmayı sağlamada önemlidir. Bu bilgiler sayesinde söz konusu mekanizma reaksiyona girer/girmelidir. Bu şekilde harekete geçen mekanizma hem eğitileni hem eğitimciyi hem de eğitimin içeriğini sürekli bir gelişim süreci içinde bulundurur.

Doğal ayetler referans alınarak hazırlanan eğitim programı statik olamaz. Zira bu ayetlerin ait olduğu sistemler dinamik sistemlerdir. Bu 
sistemin her bir materyali sistem içinde dinamik bir yapıya sahip olduğundan bu materyaller göz önüne alınarak hazırlanacak eğitim programları da dinamik olacaktır. Materyallerin ait olduğu sistem bu dinamizmi kendiliğinden sağlar. Zira insanı meydana getiren bileşenlerden biri de bu sistemin bir parçasıdır. Bu parça da bu sistemin işleyişine tâbidir. Sistemin değişimi insanın da değişimini gerektirir. Bu sebeple, eğitim programı, bu değişim ve bu dinamizm göz önüne al1narak yapılmalıdır. Aksi takdirde ister geçmişe ait isterse yeni olsun bu tür programlar eğitimin kalitesini düşürür ve beklenilen sonucu vermez.

Kur'an ayetleri doğaya ait materyelleri ve bu materyallerin ait olduğu sistemleri insan eğitimi için kullanmaktadır. Ayrıca Kur'an ve doğa ayetleri hem eğitimin içeriği hem de bu eğitimin nasıl gerçekleştirileceği ile ilgili temel esaslar (atribü) seviyesinde bilgi verir. Kur'an'daki peygamber sahneleri ile çevremizdeki hayvanların yaşantısı buna örnektir. Ancak bunları anlamak için kullanılacak yöntem çok önemlidir. Yöntemler tespit edilirken ve elde edilirken kullanılan materyallerin ait olduğu sistemlerden yararlanılır. Yöntemler materyallerden bağımsız, materyaller de ait olduğu sistemlerden bağımsız hazırlanamaz; hazırlanmamalıdır.

Hz. Muhammed Kur'an ayetleri ile eğitilmiştir (el-Acluni, 1351, s.1/70). Eğitilmesinde kullanılan materyaller de Kur'an'da apaçık ifade edilmiştir. Eğitilme süreci ayet-i kerimede; "Seni dalâlette buldu sonra hidayete erdirdi." (Kur'an, 93:7) şeklinde açıklanmıştır. Hz. Muhammed'in vahiy indirilmeden önce dalalet halinde olduğunu bu ayet ifade etmektedir (Yazır, 1992, s.9/280). Vahyin onun kalbine indirilmesi 
neticesinde ise hidayete kavuştuğu söylenmektedir.

Peygamberi dalaletten hidayete erdiren Kur'an ve doğa ayetleridir. $\mathrm{Bu}$ ayetler sayesinde peygamberimiz hidayete ermiştir. Diğer peygamberlerin eğitimi konusunda da fizikî varlıkların kullanıldığına şahit olmaktayız. Kur'an, mesajını genellikle evreni oluşturan kelimeleri kullanarak anlatmıştır. Yani vahiy mesajını ulaştırırken evrenin dilinden yararlanmıştır.

Doğa ve Kur'an ayetleri incelenirken bu ayetlerin dili ile insanın kullandığı dil arasında bir uzlaşma sağlanmalıdır. İlk aşamada bu iki dil arasında sağlam köprülerin kurulması gerekir. Eğer bu köprü sağlam bir şekilde kurulmazsa bunlar arasında uygun ve istenilen geçişlerin olması mümkün değildir. Sistem ihlalleri yaşanabilir. Bu nedenle insanın kuracağı dil tutarlı ve isabetli olmalıdır.

Hidayete ulaştırmada kullanılan materyaller vardır. $\mathrm{Bu}$ materyaller eşdeğerlilik sınıfının bir üyesi olarak kullanılmıştır. Kur'an'1 incelediğimizde bu materyallerin rabbimizin yarattığı eşya olduğu birçok ayette açıkça söylenmiştir. Kur'an'da, “Yaratan Rabbinin adıyla oku!” (Kur'an, 96:1) derken işaret edilen materyaller yaratılmış olan varlıklardır. Hatta bu konuya açıklık getirmek için ayetin devamında insanın “alak”tan yaratıldığına dikkat çekilmiştir.

Kisaca ifade etmek gerekirse eğitim sürecinde fizikî sistemin materyallerinin kullanıldığını görmekteyiz. Kur’an’da geçen; “(İnsanlar) devenin nasıl yaratıldı ̆̆ına, göğün nasıl yükseltildiğine, dă̆ların nasıl dikildiğine, yeryüzünün nasıl yayıldı̆̆ına bir bakmazlar 
$m \imath$ ?” (Kur’an, 88:17-20) ayetlerinde; deve, gök, dağlar ve yeryüzü mesaj taşıyan varlıklardır. Bu ayetlerde de yine insanın yaşadığ 1 fiziksel sisteme ait materyaller kullanılmıştır. Bu tür ayetler eğitimde fizikî sistemin materyallerinin ağırlıklı olarak kullanıldığını göstermektedir.

Doğa ve vahiy, yaratıcının mesajlarını anlatmada birbirlerine destek olurlar. Bu destek mesajın anlaşılma kalitesi açısındandır. Yazılı metni entelektüel soyutlama kabul edersek doğanın kendisi de entelektüel bir somutlamadır. Entelektüel soyutlamadan entelektüel somutlamaya geçişin birebir olması da mesajın anlaşılma kalitesini gösterir.

\section{Din Eğitiminde Sistem Dışı Objelerden Yararlanma}

Kur'ân fizikî evrenimizin dışı hakkında da bilgiler sunar. Zira evrenimizi meydana getiren sistemden farklı olarak sistem dışına dair bilgiler de vardır. Sistemimize ait bilgileri kullanarak entelektüel somutlamalara sahip olamadığımız olaylar ve objeler bulunmaktadır. Bunlar sistem dışına ait varlıklardır. Sistem dışı diye nitelendirdiğimiz bu varlıklar da kendi aralarında bir sistem oluşturabilirler.

İnsanın eğitiminde öncelikle fizikî sistemin materyallerinden yararlanılmaktadır. Yani eğitim sürecinde öncelikle fiziki sistem kullanılmıştır. Kur'an'daki Nebe suresinin ilk ayetleri incelendiğinde bu durum açıkça görülür. Fiziki sisteme ait materyallerle eğitimi gerçekleşmeyen insanlar için de sistem dışına dair materyaller ve karşılaşacağ 1 olaylar kullanılmıştır. Bu bağlamda aynı surede, "Şüphesiz, azgınların 
barınă̆ı olacak cehennem pusuda beklemektedir.” (Kur’an, 78:21-22) denilmektedir. Burada cehennemin gözetlemekte olduğu, azgınları beklemekte olduğu, orada rahatlığın olmayıp aksine azabın olduğu ifade edilmektedir. İnsanın eğitimi için bu tür anlatımlardan istifade edilmektedir. Böylece insanın hem azgın (tagun) olması engellenmeli hem de böyle vasıfları varsa bir an önce temizlenmesi sağlanmalıdır.

Sistem dişı varlıklar ve olaylar bu tarz anlatımlarla insan eğitiminde kullanılmaktadır. Kısaca ifade etmek gerekirse; Kur'an din eğitiminde sistem dışına ait varlıklardan ve olaylardan istifade ederek kişinin eğitilmesini istemektedir. Bu durum herkesin anlayacağı bir dilin olduğuna işaret eder. Hz. İbrahim gibiler varlıkları inceleyerek kazanması gereken davranışları kazanmıştır. Bu vasıftaki insanlar için cehennem gibi enstrümanların kullanılmasına gerek kalmayabilir.

Aynı şeyi Nebe suresinin akışında da görürüz. Öncelikle fizikî sistemin varlıkları ve aralarındaki ilişkiler gösterilerek insanın talimi gerçekleştirilir. Bu yolla eğitime direnenler de diğer sistemin elemanlarından istifade edilerek eğitilir. Ayrıca eğitilmişlerin veya eğitime cevap verenlerin daha nitelikli hâle gelmesi, kazandığı hâlleri devam ettirmesi için de cennet gibi sistem dişı varlık ve olayları anlatarak eğitimde sürekliliği ve kaliteyi yakalamak amaçlanmıştır. Bunların hepsi özgür iradenin yetkisine verilmiştir. İsteyen hidayete, isteyen de dalâlete ulaşabilir.

Neticede hem sistem içine hem de sistem dışına ait bilgilerin kalbimize gönderilmesi gerekmektedir. Enformasyon değeri olan bu 
veriler akletme (Kur'an, 22:46) ve fikhetme (Kur'an, 17:46) özelliğine sahip olan kalbimize beyin tarafından gönderilmelidir. $\mathrm{Bu}$ enformasyonun her yönüyle ekonomik olarak bireylere ulaştırılması işlemine eğitim diyoruz. Din dilinde ise buna kulluk adını verebiliriz.

\section{Sonuç}

Varlıklar (doğal ayetler) ait oldukları sistem ve bu sistemde geçerli olan kanunlar çerçevesinde hayatlarını ve kendilerine yüklenen misyonu yerine getirirler. Bu sebeple herhangi bir varlığ 1 veya olayı incelerken ve bunları eğitimde kullanırken öncelikle bunların ait olduğu sistemi ve sınırlarını tespit etmemiz gerekir. Aksi takdirde göz önüne alınan varlıklarla ilgili sağlıklı kararlara varamayız. Bu varlıkların sistem meydana getirmesi için de kısaca şu iki şartı sağlamaları gerekmektedir:

1. Birbirleriyle ilişkili bir bütün oluşturmaları

2. Aralarında sürekli ve düzenli bir etkileşimin olması

$\mathrm{Bu}$ bileşenleri sağlamayan birlikteliklere sistem diyemeyiz. Bu iki bileşen doğal sistemlere Rabb'imiz tarafından verilmiştir. Ancak eğitim sistemi gibi sistemler bizler tarafından kurulmaktadır. Bizlerin kuracağı yapıların sistem olması bu iki bileşeni sağlayıp sağlamamasına bağlıdır. Bunun için de epistemik belirsizliklerin en aza indirilmesi şarttır.

Nitelikli anlama için epistemik çalışmalar önemlidir. Bu çalışmalar materyal olarak fiziki sistemimizi kullanır. Bu çalışmalar sonucunda elde edilen ürünler formel eğitim inşasında önemli işleve sahip- 
tir. Nitekim Kur'an ayetleri bizlere mesaj ulaştırırken doğa ayetlerini kullanmıştır. Bu nedenle din eğitimi müfredatı ve uygulama teknikleri hazırlanırken evrene ve onu oluşturan sistemlerin rehberliğine başvurulmalidir.

Din eğitiminde evrenimize ait herhangi bir varlıktan istifade etmek istediğimizde onunla az veya çok ilgili olan bütün bileşenler tespit edilmelidir. Daha sonra bu bileşenlerin incelediğimiz varlıkla olan irtibatı ve ilişkisi ilmî olarak ortaya konulmalıdır. Aksi takdirde göz önüne aldığımız varlıktan yola çıkarak kaliteli ve sağlıklı bilgiye ulaşamayız.

$\mathrm{Bu}$ süreçte kendisinden istifade edilecek varlıklar doğru seçilmelidir. Bunlar eğitim materyalleridir. Daha sonra bu materyallerin ait olduğu sistemin analizi yapılıp bu sistemin bağlı olduğu kurallar ve kanunlar ortaya konulmalıdır. Sonunda bunlarla reaksiyona girebilecek ve böylece insanın yeteneklerini aktüalize edecek bir eğitim düzeneği hazırlanmalıdır. Bu arada din eğitiminde kullandığımız yöntemin de bir sistem olması gerekir.

Din eğitimi, tespit edilen sistemler ve bu sistemlerin işleyişleri çerçevesinde performans gösterecek şekilde programlanmalı ve uygulanmalıdır. Her performans hem eğitimciye hem de eğitilene deneyim kazandırır. Bu iki değişkenin birbirine göre değişimininin devamlı olarak denetlenmesi önemli bir husustur. Olumlu ve faydalı bu geri beslemeler (feedback) performansın deneyime göre pozitif bir eğime sahip olmasını sağlar. Bizler ancak bu ikisinin doğru orantılı olarak arttığını göz- 
lemlediğimizde ve bu artışın ürünün kalitesini sağladığını gördüğümüzde uygulanan eğitimin nitelikli olduğundan bahsedebiliriz.

$\mathrm{Bu}$ arada performans ve deneyim bir sonraki din eğitimi uygulamalarının da billurlaşmasını (rafinasyon) sağlayacaktır. Rafinasyon dinamik süreçlerde ortaya çıkar. Doğal ayetlerin hem kendileri hem de bizlerde oluşturdukları bilgiler dinamik bir hüviyettedir. Bundan dolayı doğal ayetler referans alınarak hazırlanan eğitim programı statik olamaz. Bu ayetlerin ait olduğu sistemler dinamik olduğu için kurulacak olan eğitim sistemi de dinamik olur. Dinamik eğitim sisteminde bütün ilmî disiplinler görev alır/almalıdır.

Kur'an ayetlerinin oluşturduğu sisteme baktığımızda bunların bütün disiplinlere temel özellikler seviyesinde işaret ettiğini görürüz. Ayrıca Kur'an sistemine mânâ ve mazmun açısından baktığımızda matematik-mantık yapısına sahip olduğunu görürüz. Beyanların çelişkisiz ve bir bütün olması bizi bu sonuca götürmektedir. Aynı şekilde doğada da tamlık ve tutarlılık görülür. Bu zaviyeden bakıldığında Kur'an'ın anlatmak istediği mesajlar kümesi ile doğanın anlatmak istediği mesajlar kümesinin eşdeğer olduğunu söylemek mümkündür.

Dolayısıyla bu disiplinleri dinî veya dinî olmayan şeklinde bir ayrıma tâbi tutmak doğru değildir. Zira gerek Allah'ın sözlerini içeren Kur'an kitabında ve gerekse Allah'ın yarattığı kâinat kitabında böyle bir ayrımın olmadığını rahatlıkla görürüz.

$\mathrm{Bu}$ açıdan bakıldığında çoklu disiplinler (multi-disipliner) yaklaşımının çok önemli olduğunu söyleyebiliriz. Bu yaklaşım sayesinde 
ilmî metodoloji daha kapsamlı hâle gelir. İlmî metodoloji ilmî disiplinleri, ilmî disiplinler de ilmî metodolojiyi besler. Bu yaklaşımdan beslenen bir metodolojinin din eğitiminde kullanılması çok önemlidir. $\mathrm{Bu}$ metodolojiden yola çıarak öncelikle doğa ve Kur'an ayetleri gereği gibi anlaşılmalı daha sonra da din eğitimi programı hazırlanmalıdır.

Kur'an ayetlerini bu bağlamda incelediğimizde, insanı ilgilendiren ve etkileyen hiçbir şeyi dışarıda bırakmadığını görürüz. Bu ilmî anlayışın prensiplerini ortaya koyan İslamiyet, evrenimizi Allah'ın bir eseri olarak görürken, Kur'an'1 da onun kâinat hakkındaki sözlerinin bir özeti olarak değerlendirmektedir. Buna göre evren de o sözlerin bir açılımıdır. Bu açıdan baktığımızda, Kur'an-1 Kerim'i kâinatın kelimelere dökülmüş hâli olarak görebiliriz.

İlim dilinin sağladığı imkânlarla ve yukarıda bahsettiğimiz metodolojilerle, din eğitiminin temelini teşkil eden Kur'an'ı anlamaya çalı̧̧manın birbirine eşdeğer ve nitelikli sonuçlar çıkarmamıza yardımcı olacağını ifade edebiliriz. Ancak bu çaba itibar kazandıracak düşüncesiyle değil de özellikle kişinin eğitiminde önemli rol oynadığından dolayı olmalıdır.

Doğa ve Kur'an ayetleri incelenirken bu ayetlerin dili ile insanın kullandığı dil arasında bir uzlaşma sağlanmalıdır. İlk aşamada bu iki dil arasında sağlam köprülerin kurulması gerekir. Eğer bu köprü sağlam bir şekilde kurulmazsa bunlar arasında uygun ve istenilen geçişlerin olması mümkün değildir. 


\section{Kaynakça}

Bilgili, F. M. ve Yavuz, Ö. (2011). Yöntem bilim bağlamında doğa-Kur'an eşdeğerliliği. Konya: Çizgi Kitabevi.

Bilgin, B. (1995). Eğitim bilimi ve din ĕgitimi. Ankara: Yeni Çizgi Yayınları.

Çantay, H. B. (1984). Kur'ân-ı Hakîm ve Meâl-i Kerîm (1). İstanbul: Elif Ofset.

el-Acluni, İ. M. (1351). Keşfü'l Hafa (c,1). Beyrut.

İbn Cemâa, S. B. (1998). İslam geleneğinde öğretmen-öğrenci. (M. Ş. Aydın, Çev.). İstanbul:Maarif Yayınları.

King, J. P. (2003). Matematik sanatı. (N. Arık, Çev.). Ankara: Tübitak Popüler Bilim Kitapları.

Kur'an-1 Kerim.

Najmuddin, Y. (1981). Knowledge and education in Islam. The M. W. L. Journal, 8(9), 8-13.

Nasr, S. H. (2006). İslam ve bilim. (İ. Kutluer, Çev.). İstanbul: İnsan Yayınları.

Özenli, S. (1994). İlim ve teknolojinin olumlu ilkeleri: Ders notlart. Adana: İletişim Ofset.

Özenli, S. (1999). İlmî sohbetler. Adana:Karakuşlar Yayınları.

Penrose, R. (2005). Büyük küçük ve insan zihni (C. Türkman, Çev.). İstanbul: İzdüşüm Yayınları. 
Selçuk, M. (1990). Çocuğun ĕgitiminde dinî motifler. Ankara: T.D.Vakfi.

Tozlu, N. (1997). Eğitim felsefesi. İstanbul: M.E.B.

Yazır, E. H. (1992). Hak dini Kur'an dili (İ. Karaçam, E. Işık, N. Bolelli, A. Yücel, Sad.). İstanbul: Azim Yay. 